\title{
Effect of co-existing plant specie on soil microbial activity under heavy metal stress
}

\author{
${ }^{1 *}$ C.O. Nwuche; ${ }^{2}$ E.O. Ugoji \\ ${ }^{1}$ Department of Microbiology,University of Nigeria, Nsukka, Nigeria \\ ${ }^{2}$ Department of Botany/Microbiology,University of Lagos, Akoka, Lagos, Nigeria \\ Received 23 January 2010; $\quad$ revised 21 April 2010; accepted 3 June 2010 ; available online 1 September 2010
}

\begin{abstract}
The influence of plant primary compounds on the activity of soil microbial communities under heavy metal stress was studied in a pot-culture field experiment conducted in a green house. Amaranthus spinosus was cultivated in an agricultural soil previously amended in the laboratory with solutions of different trace elements in two separate treatment modes: singly and in combination. Culture-independent metabolism based indices such as the rate of carbon and nitrogen mineralization, microbial biomass carbon and soil basal respiration were monitored fortnightly over a period of six weeks. Result shows that plant detritus have significant modifying effect on soil microbe-metal interactions. Data on microbial and biochemical processes in the respective mesocosms did not vary from control; not even in mesocosms containing very high concentrations of copper, zinc and nickel. The soil microbial biomass carbon and the rate of carbon and nitrogen cycling were not impeded by the respective metal treatment while the respiration responses increased as a result of increase in metabolic activity of the soil microbes. The plant based substrates enabled the soil microflora to resist high metal contamination because of its tendency to absorb large amounts of inorganic cations.
\end{abstract}

Keywords: Basal respiration; Greenhouse; Mesocosms, Substrates; Microbial biomass carbon; Mineralization; Pot-culture

\section{INTRODUCTION}

Soil heterotrophic microbial communities are the primary mediators of key biological processes in soil such as organic matter degradation and mineralization (Okafor and Opuene, 2007; Li et al., 2009). The considered processes control ecosystem carbon and nitrogen cycling. Therefore, they play important roles in maintaining soil ecosystem quality and functional diversity, as well as represent a potential link between plant diversity and ecosystem function (Schloter et al., 2003; Zak et al., 2003; Gueu et al., 2007; Li et al., 2009). Resource availability for the soil microflora is limited to organic compounds of decayed leaves and root exudates which they use to generate cellular energy (Smith and Paul, 1990; Panjeshahi and Ataei, 2008). Plant species differ biochemically; as a result, the rate of production, quantity and range of organic compounds in detritus vary widely (Hooper et al., 2000; Zak et al., 2003; Suthar and Singh, 2008 ). Since plants are the main supplier of organic materials in

\footnotetext{
\4Corresponding Author Email: charlesnwuche@yahoo.com
} Tel./Fax: +2348033728524 terrestrial ecosystem, they indirectly affect soil microbial communities, as well as diverse ecosystem processes especially at the rhizosphere (Kowalchuk et al., 2002). Despite this observation, few studies have actually investigated the influence of plants on the structure, composition and activities of soil microorganisms (Stephan et al., 2000; Torkian et al., 2007; Oshode et al., 2008; Cherian and Jayachandran, 2009) because of the challenge associated with studying microbial diversity in soil.

The vast majority of soil microbes (> $95 \%$ ) are not cultivable using currently available techniques. Also, morphological characters are insufficient to allow taxonomy and definition of bacterial specie is not always very clear (Kowalchuk et al., 2002). When heavy metals are retained in the soil by repeated and uncontrolled additions, they interfere with key microbial and biochemical processes which alter ecological balance. The accumulation of heavy metals in soil at toxic levels is basically due to human activity such as agriculture, mining and industry (Abdel-Ghani 
and Elchaghaby, 2007; Babel and Opso, 2007; AbdelGhani et al., 2009; Igbinosa and Okoh, 2009; Malakootian et al., 2009; Moreno et al., 2009; Zvinowanda et al., 2009). At present, Nigerian threshold levels above which heavy metals are considered toxic in soil are being worked out. Heavy metals are known to be toxic to soil microbiota which have been reported to be far more sensitive than soil fauna and macrophytes (Giller et al., 1998).Therefore, microbial and biochemical parameters are sufficient and very useful indices for monitoring the level of pollution in soil (He et al., 2003). Toxic metals cause protein denaturation and damages microbial cell membranes, interfering with their growth, morphology and metabolism (Leita et al., 1995).

While numerous reports exist on the effects of heavy metals on soil microbial processes, few scientific information is however available on the possible effects of co-existing plant species on the soil microbial dynamics under heavy metal pollution. In the previous study (Nwuche and Ugoji, 2008), the authors observed that different forms of metal interactions exert some modifying influence on metal toxicity which could be competititive, additive or antagonistic. Also, depending on soil characteristics

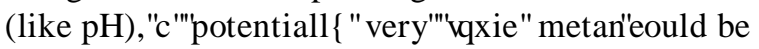
without effect on the soil microbiota because $\mathrm{pH}$ influences the solubility, mobility and bioavailability of metal species. Thus, elevated metal concentrations in soil are not indicative of pollution or any selective pressure due to its presence on soil microbiota.

In the present study, how plants influence the activities of the soil heterotrophic microflora under heavy metal stress was examined in more detail. Since plants constitute the primary channel through which organic matter enter the ecosystem, it was hypothesized that (a) the influence of the plant would be greatest at the root regions (i.e. rhizoplane and rhizosphere) which are areas under the greatest influence of the growing plant (b) the detritus discharged by plant roots will adsorb considerable amounts of toxic metal ions thus masking the metal effects on the soil communities. These hypotheses were examined in a field pot - culture experiment which was conducted in a green house at $28 \pm 2{ }^{\circ} \mathrm{C}$ by monitoring a variety of culture-independent metabolism based responses such as rate of $\mathrm{C}$ and $\mathrm{N}$ mineralization, microbial biomass carbon and basal respiration assays as critical parameters.

\section{MATERIALS AND METHODS}

\section{Study sites and sampling}

This study was conducted within the research facility of Federal Institute of Industrial Research (FIIRO) Oshodi, Lagos - Nigeria during six weeks. The city lies within latitude $6^{0} 33^{1} \mathrm{~N}$ and $3^{0} 20^{1} \mathrm{E}$. It enjoys a bimodal rainfall pattern with the rainy season lasting from March to November each year and about a two-week break in the mouth of August. Land elevation is approximately $1500 \mathrm{~m}$ above sea level while average ambient temperature is $28 \pm{ }^{\circ} \mathrm{C}$. Soil for experiment was from an agricultural field plot located within the institute. It was covered with green luxuriant vegetation at time of sampling. Soil cores were collected from more than ten random locations at 5 $15 \mathrm{~cm}$ depth using a $2.5 \mathrm{~cm}$ diameter soil auger. The cores were composited, homogenized and seived (meshsize $<2 \mathrm{~mm}$ ) to remove stones, plant debris and other organic materials. The soil was kept at $28 \pm 2^{\circ} \mathrm{C}$ for 7 days to stabilize from the disturbance caused by sampling and sieving. The soil type was classified as clayey - loam and the main physicochemical characteristics were $\mathrm{pH}=7.23$; carbon $(\%)=4.87$; total nitrogen $(\%)=0.24$; microbial biomasscarbon $(\mu \mathrm{g} / \mathrm{g})=185.58$; soil basal respiration $(\mu \mathrm{g}$ of $\mathrm{c} / \mathrm{g})=$ 2.557; total phosphorus $(\%)=0.37$; water holding capacity (WHC) \% = 51; heavy metals (mg/kg/soil) $\mathrm{Cu}=6.65, Æ \mathrm{n}=12.0, \mathrm{Ni}=1.63 . \mathrm{Pb}, \mathrm{Cd}, \mathrm{Hg}$ and $\mathrm{Cr}$ were not detected. Seived and pre-incubated cores were thoroughly mixed with basal fertilizers before dispersing about $1 \mathrm{~kg}$ into each of eight $22 \mathrm{~cm}$ (diameter) $\times 25 \mathrm{~cm}$ (height) plastic pots called mesocosms. The pots were labelled A $-\mathrm{H}$. Subsequently, solutions of analytical grade (Sigma) sulphate ( $\left.\mathrm{SO}^{2-}\right)$ salts of zinc, copper and nickel made by dissolving appropriate concentrations and combinations of each metal salt in distilled water were applied to each of the mesocosms as previously reported (Nwuche and Ugoji, 2008). The content of each mesocosm was mixed again in a miniature plastic cement mixer. The plant used for the study was Amaranthus spinosus.It was previously grown in nursery for about two weeks. When the plant developed $2-3$ leaves and attained a height of $4-5$ $\mathrm{cm}$, they were transplanted to the mesocosms. Each mesocosm had three replications and total plant 
density of fifteen. The mesocosm which served as control had no heavy metal amendment. The moisture content of each pot was controlled periodically by gravimentry and distilled water was added when necessary to maintain the water holding capacity at about $50 \%$. Pot cultures were maintained by frequent weeding to remove small invading plants with little or no soil disruption. For sample collection and analyses, about five holes (1.5 cm diameter) were made in each mesocosm to a depth of $15 \mathrm{~cm}$. Soil taken around the rhizosphere were compsited to make up a sample weight of $100 \mathrm{~g}$. The rates of microbial carbon and nitrogen mineralization, respiration responses and microbial biomass carbon were assayed by the second, fourth and sixth week post-transplanting.

\section{Biochemical and microbiological analysis}

Total soil organic carbon (\%) was determined by the dichromate digestion method (Kalembasa and Jenkinson, 1973). The digestion mix contained $20 \mathrm{~g}$ $\mathrm{Na}_{2} \mathrm{Cr}_{2} \mathrm{O}_{5} .2 \mathrm{H}_{2} \mathrm{O}, 400 \mathrm{~mL} \mathrm{H}_{2} \mathrm{SO}_{4}$ and $200 \mathrm{~mL} \mathrm{H}_{3} \mathrm{PO}_{4}$, diluted with distilled water to 1litre to make $9 \mathrm{~N}, 15 \mathrm{~N}$ and $0.4 \mathrm{~N}$ respectively. The digestion mix was dispersed by a piston burette. The soil, in a $250 \mathrm{~mL}$ quick fit flask with a Liebig condenser was refluxed for 120 mins with 25 mLof the digestion mix; the temperature at reflux was $151^{\circ} \mathrm{C}$. After cooling, 100 $\mathrm{mL}$ of water was added, then $2-3 \mathrm{~mL}$ indicator solution $(0.1 \mathrm{~g}$ of barium diphenylamine $\mathrm{P}$ - sulfonate and $10 \mathrm{~g}$ of barium chloride dihydrate made up to 200 $\mathrm{mL}$ with water) and the unused dichromate titrated against $0.4 \mathrm{~N}$ ferrous ammonium sulphate in $0.75 \mathrm{~N}$ sulphuric acid. The amount of dichromate consumed was that in blank digestion without soil, less thDW remaining in the soil digestion. The ferrous solution was standardized against potassium dichromate. $1 \mathrm{ml}$ of $0.4 \mathrm{~N}$ - dichromate is consumed by $1.2 \mathrm{mg}$ of soil organic carbon.

Nitrogen mineralization was determined by measuring the production of $\mathrm{N}\left(\mathrm{NH}_{4}^{+}\right.$and $\left.\mathrm{NO}_{3}^{-}\right)$during incubation. Incubations were carried out on $50 \mathrm{~g}$ (dry weight) of soil moistened with distilled water to $50 \%$ WHC in an oven at $28{ }^{\circ} \mathrm{C}$ for 21 days. $\mathrm{NH}_{4}^{+}$and $\mathrm{NO}_{3}^{-}$ contents were measured by the Nessler and phenoldisulfonic methods, respectively. For the measurement of $\mathrm{NH}_{4}^{+}, 10 \mathrm{~g}$ soil sample (dry weight) was shaken with $50 \mathrm{~mL}$ of KCL $(2.0 \mathrm{M})$ for $30 \mathrm{~min}$. Filtration was performed after centrifugation for 10 min at $5000 \mathrm{x}$ g. The $\mathrm{NH}_{4}^{+}$was measured with a spectrophotometer after adding 2 drops of stabilizer dispenser and $0.4 \mathrm{~mL}$ of Nessler reagent per $10 \mathrm{~mL}$ of filtrate (Dai et al., 2004). For the measurement of $\mathrm{NO}_{3}^{-}$ , a $10 \mathrm{~g}$ soil sample was shaken with $50 \mathrm{~mL}$ of $\mathrm{CuSO}_{4}$ $(0.01 \mathrm{M})$ for $30 \mathrm{~min}$. Then filtration was performed after addition of $0.2 \mathrm{~g}$ of $\mathrm{Ca}(\mathrm{OH})_{2}$ and $\mathrm{MgCO}_{3}$ powder to the suspension. $2 \mathrm{~mL}$ of filtrate was evaporated at 80 ${ }^{\circ} \mathrm{C}$ to dryness and then $2 \mathrm{~mL}$ of phenoldisulfonic acid, $20 \mathrm{~mL}$ of distilled water and $10 \mathrm{~mL}$ of concentrated $\mathrm{NH}_{4} \mathrm{OH}$ were added (Bremner, 1965). The colour produced by phenoldisulfonic acid was measured with a spectrophotometer. The net ammonification and nitrification rate was calculated as the difference of $\mathrm{N}$ $-\mathrm{NH}_{4}^{+}$and $\mathrm{N}-\mathrm{NO}_{3}^{-}$contents before and after incubation. The mineralization rate of total organic $\mathrm{N}$ was estimated by sum of ammonification and nitrification rate.

Microbial biomass $\mathrm{C}\left(\mathrm{C}_{\text {mic }}\right)$ was determined by the fumigation - extraction method (Vance et al., 1987). $10 \mathrm{~g}$ of sample were fumigated with chloroform and another $10 \mathrm{~g}$ were not fumigated. Carbon was extracted with $40 \mathrm{~mL}$ of $0.5 \mathrm{M} \mathrm{K}_{2} \mathrm{SO}_{4}$ solution from fumigated and non - fumigated samples and measured in the centrifuged and filtered extracts using a soluble organic $\mathrm{C}$ analyzer. Microbial biomass $\mathrm{C}\left(\mathrm{C}_{\text {mic }}\right)$ was calculated by the expression:- $\mathrm{C}_{\text {mic }}=\mathrm{C}_{\text {extracted }} \mathrm{X} 2.66$ where $\mathrm{C}_{\text {extracted }}$ is the difference between the $\mathrm{C}_{\text {extracted }}$ from fumigated samples and $\mathrm{C}_{\text {extracted }}$ from non fumigated samples.

Soil basal respiration was analyzed by placing $20 \mathrm{~g}$ portions of soil per treatment in $100 \mathrm{~mL}$ pyrex glass flasks. The flasks were covered with aluminum foil and secured with a septum. During sampling, the headspace of each flask was equilibrated with the soil atmosphere by pumping with $10 \mathrm{~mL}$ syringe. Thereafter, $100 \mu \mathrm{L}$ of atmospheric air was injected and the same volume of gas removed for the $\mathrm{CO}_{2}$ analysis using a nitrogen carrier with a flow rate of $50 \mathrm{~mL} / \mathrm{min}$ $\mathrm{CO}_{2}$ evolution was measured by a Beckman model 865 infra-red gas analyzer (Beckman, La Habra, California) (Petersen and Klug, 1994).

The moisture content of soil was measured gravimetrically by drying $50 \mathrm{~g}$ of soil sample at $105^{\circ} \mathrm{C}$ for $24 \mathrm{~h}$. The total metal content of soil before amendment was determined post digestion by the atomic adsorption spectrophotometer. Soil $\mathrm{pH}$ was measured on air dried soil in $0.01 \mathrm{M} \mathrm{CaCl}_{2}$ using $1: 2\left({ }^{\mathrm{w}} /{ }_{\mathrm{v}}\right)$ soil: liquid ratio. 


\section{Analysis of results}

Results were analyzed by two - way analysis of variance (ANOVA) at $95 \%$ confidence interval to determine significant differences between the means of treatment and levels of contamination.

\section{RESULTS AND DISCUSSION}

Plant influence had significant effect on the activities of the microbial community in this study. Results show that the measured microbial and biochemical parameters significantly increased in the respective mesocosms. The rates of carbon and nitrogen mineralization (Tables 1 and 2) showed that the microbial activities in the respective mesocosms did not vary significantly from the control treatment. Carbon increased moderately through the fortKQghtly measurements until reaching the highest recorded peak of $5.17 \%$ in the $\mathrm{Cu}: \mathrm{Zn}$ mesocosm. Particularly noteworthy was that both control treatment and the $\mathrm{Cu}$ amended mesocosm had the same value of $4.92 \%$ which were also the least by the end of experiment. The rate of nitrogen mineralization was somewhat identical to the pattern already described. Nitrogen increased to its peak of $0.32 \%$ in the $\mathrm{Cu}: \mathrm{Zn}$ mesocosms, while Ni treatment was the least at $0.28 \%$. Both control and $\mathrm{Zn}$ mesocosms had same incremental rate $(0.29 \%)$ just as $\mathrm{Cu}: \mathrm{Ni}$ and $\mathrm{Ni}: \mathrm{Zn}(0.31 \%)$ by the $6^{\text {th }}$ week of experiment.

In order words, there was no tendency towards accumulation suggesting that the primary microbial nutrient cycling processes were not impeded by the metal treatments. Impeded litter decomposition is known to be a common feature of heavy metal polluted soils (Illmer and Schinner 1991; Marschner and Kalbitz, 2003). The degree of impedance are usually determined by the rates of carbon and nitrogen mineralization. Thus, under heavy metal pollution, the rate of these activities become impaired while $\mathrm{C}$ and $\mathrm{N}$ accumulates in soil. Zak et al., (2003) had earlier reported that carbon substrates produced by plants significantly enhanced the rates of microbial processes that mediate ecosystem $\mathrm{C}$ and $\mathrm{N}$ cycling by affecting microbial community composition and activity. In our study, there were no difference between the mesocosms with high concentration of metal treatment and those with much less metal amendment nor was any effect arising from possible metal interactions deducible from the assays on the rates of carbon and nitrogen mineralization.It had been previously reported (Nwuche and Ugoji, 2008) that $\mathrm{Cu}$ and $\mathrm{Cu}: \mathrm{Zn}$ treatment elicited the highest inhibitory effects among all the other treatment when incubated in an agricultural soil over a duration of six weeks. Here, the soil microbial process within the $\mathrm{Cu}$ and the $\mathrm{Cu}: \mathrm{Zn}$ mesocosm differed neither with the control treatment nor data obtained from the other mesocosms. The soil plant carbon exudates may account for this because organic materials are known to absorb considerable amounts of inorganic cations including toxic metal ions by an ion exchange mechanism or by specific absorption (He et al., 2005; Perez - de Mora et al., 2007). Thus available carbon substrates enable the microbial community to grow and resist unusually high heavy metal contamination in soil (Moreno et al., 2009). Depending on dose factors and metal types, heavy metals cause protein denaturation, interferes with the integrity of microbial cell membranes impairing their growth, morphology and metabolism (Leita et al., 1995; Giller et al., 1998). Plant induced changes on microbial community composition and activity have long been reported (Rorga et al., 1994; Marshner et al., 2001; Zak et al., 2003; Carney et al., 2004; Carney and Matson, 2005). In some of these studies, changes in microbial abundance and composition across a diversity gradient was found to be caused by plant productivity, rather than plant diversity as previously imagined. Thus, changes in plant communities often result in change in the type and quantity of organic matter input to soil (Hooper et al., 2000) to the extent that ultimately selects soil microorganisms with appropriate catabolic capabilities to mineralize the diverse suite of organic products entering the soil. Microbial biomass $\mathrm{C}$ is a major component of microorganism and is commonly regarded as a sensitive indicator of change in microbial community size and structure (Vig et al., 2003). Several previous studies (Giller et al., 1998; Nwuche and Ugoji, 2008) have reported a decrease in soil microbial biomass as a result of long term exposure to trace metal contamination. Results of this study show that the soil microbial biomass increased across the mesocosms at a rate that compares significantly with the control (Table 3). 
Int. J. Environ. Sci. Tech., 7 (4), 697-704, Autumn 2010

Table 1: Effect of treatment on rate of carbon mineralization in soil (\%)

\begin{tabular}{ccccccccc}
\hline Sample & $\mathrm{A}$ & $\mathrm{B}$ & $\mathrm{C}$ & $\mathrm{D}$ & $\mathrm{E}$ & $\mathrm{F}$ & $\mathrm{G}$ \\
\hline Week & Control & $\mathrm{Cu}$ & $\mathrm{Ni}$ & $\mathrm{Zn}$ & $\mathrm{Cu}: \mathrm{Ni}$ & $\mathrm{Cu}: \mathrm{Zn}$ & $\mathrm{Ni}: \mathrm{Zn}$ & $\mathrm{Cu}: \mathrm{N}: \mathrm{Zn}$ \\
0 & 4.91 & 4.88 & 4.85 & 4.89 & 4.87 & 4.86 & 4.88 \\
2 & 4.87 & 4.68 & 4.89 & 4.95 & 4.77 & 4.95 & 4.85 \\
4 & 4.79 & 4.81 & 4.83 & 5.07 & 5.14 & 5.11 & 4.97 \\
6 & 4.92 & 4.92 & 4.97 & 5.11 & 5.09 & 5.17 & 5.86 & 4.94 \\
\hline
\end{tabular}

Table 2: Effect of treatment a rate of nitrogen mineralization of soil (\%)

\begin{tabular}{|c|c|c|c|c|c|c|c|c|}
\hline iample & $\mathrm{A}$ & B & $\mathrm{C}$ & $\mathrm{D}$ & $E$ & $\mathrm{~F}$ & $G$ & $\mathrm{H}$ \\
\hline Week & Control & $\mathrm{Cu}$ & $\mathrm{Ni}$ & Zn & $\mathrm{Cu}: \mathrm{Ni}$ & Cu:Zn & Ni:Zn & Cu:N:Zn \\
\hline 0 & 0.24 & 0.23 & 0.22 & 0.24 & 0.23 & 0.24 & 0.25 & 0.22 \\
\hline 2 & 0.27 & 0.28 & 0.24 & 0.27 & 0.25 & 0.25 & 0.26 & 0.26 \\
\hline 4 & 0.29 & 0.28 & 0.27 & 0.31 & 0.27 & 0.28 & 0.28 & 0.28 \\
\hline 6 & 0.29 & 0.31 & 0.28 & 0.29 & 0.31 & 0.32 & 0.31 & 0.27 \\
\hline
\end{tabular}

Table 3: Effect of treatment on biomass carbon of soil $(\mu \mathrm{g} / \mathrm{g})$

\begin{tabular}{ccccccccc}
\hline Sample & $\mathrm{A}$ & $\mathrm{B}$ & $\mathrm{C}$ & $\mathrm{D}$ & $\mathrm{E}$ & $\mathrm{F}$ & $\mathrm{G}$ \\
\hline Week & Control & $\mathrm{Cu}$ & $\mathrm{Ni}$ & $\mathrm{Zn}$ & $\mathrm{Cu}: \mathrm{Ni}$ & $\mathrm{Cu}: \mathrm{Zn}$ & $\mathrm{Ni}: \mathrm{Zn}$ & $\mathrm{Cu}: \mathrm{N}: \mathrm{Zn}$ \\
0 & 185.60 & 184.8 & 184.0 & 185.2 & 185.0 & 184.6 & 185.0 & 183.7 \\
2 & 200.45 & 197.74 & 200.56 & 200.02 & 196.1 & 197.52 & 201.65 \\
4 & 207.87 & 206.98 & 206.08 & 209.28 & 207.2 & 206.75 & 209.05 & 205.75 \\
6 & 222.72 & 218.07 & 218.96 & 220.39 & 216.45 & 215.98 & 216.45 & 214.94 \\
\hline
\end{tabular}

Table 4: Effect of treatment or respiration responses of soil microbes ( $\mu$ g of $\mathrm{C} / \mathrm{g}$ )

\begin{tabular}{cccccccccc}
\hline Sample & A & B & C & D & E & F & G \\
\hline Week & Control & Cu & Ni & Zn & Cu:Ni & Cu:Zn & Ni:Zn & Cu:Ni:Zn \\
0 & 2.56 & 2.51 & 2.54 & 2.55 & 2.56 & 2.52 & 2.54 & 2.56 \\
2 & 2.79 & 2.71 & 2.77 & 2.75 & 2.74 & 2.70 & 2.74 & 2.74 \\
4 & 2.92 & 2.86 & 2.87 & 2.85 & 2.89 & 2.83 & 2.84 & 2.87 \\
6 & 3.12 & 3.04 & 3.02 & 2.98 & 3.06 & 2.98 & 2.97 & 3.00 \\
\hline
\end{tabular}

The biomass carbon increased consistently at the same rate in the respective mesocosms through the experiment (Table 3). By the $6^{\text {th }}$ week of study, data on the microbial biomass carbon did not differ significantly from the control treatment. However, the values recorded in the $\mathrm{Zn}$ mesocosms were the highest $(220.39 \mu \mathrm{g} / \mathrm{g})$ and compares more with the control $(222.72 \mu \mathrm{g} / \mathrm{g})$ than values from the other mesocosms. In all, $\mathrm{Cu}$ and $\mathrm{Ni}$ treatments had identical rate of increase $(218.07$ and $218.96 \mu \mathrm{g} / \mathrm{g}$ respectively), just as $\mathrm{Cu}: \mathrm{Ni}(216.45 \mu \mathrm{g} / \mathrm{g})$ and $\mathrm{Ni}: \mathrm{Zn}$ (216:45 $\mu \mathrm{g} / \mathrm{g}$ ). The least recorded value of the microbial biomass was Cu:Ni:Zn (214.94 $\mu \mathrm{g} / \mathrm{g})$. It was not possible to infer any inhibition attributable to metal influence on the microbiota from data; not even in the mesocosm containing $\mathrm{Cu}$ and $\mathrm{Cu}: \mathrm{Zn}$ which caused significant decline in the soil microbial biomass carbon in previous study (Nwuche and Ugoji, 2008). Apart from the negative effect of some metal species on microbial metabolism, the modifying influence of metal ions on metal toxicity is less frequently understood. Based on this, a potentially toxic metal may become seemingly innocuous when co-existing with other metal species and vice versa. Equally, less active metal ions may become very toxic when found in 
the proximity of others. Such metal interactions are greatly influenced by soil characteristics such as organic matter and clay content (Chander and Brookes, 1991; Hattori, 1992). Because of this, the magnitude of reported effects of heavy metals on microbial activity differs widely in literature (Niklinska et al., 1998). The microbial biomass is the living component of soil and participate in many critical ecosystem processes such as nutrient transformations, degradation of xenobiotic compounds, immobilization of heavy metals and the formation of soil structure (Nannipieri et al., 2002). Plant production may have caused the reported increases in the microbial biomass across the mesocosms because of its ability to exert stimulative action on the growth, multiplication and composition of the microbial communities in the soil underneath (Stephan et al., 2000). The rates of soil respiration also increased significantly over the six week duration of the experiment following the pattern reported for the microbial biomass carbon, as well as $\mathrm{C}$ and $\mathrm{N}$ cycling. Analysis of soil respiration help to quantify the effects of metals on the total biological activity of soils because impeded soil respiration is a common feature of heavy metal polluted soils (Marschner and Kalbiltz, 2003). The rate of basal respiration (Table 4 ) of the soil microbes increased across the mesocosms just as the other parameters. Equally, the rate of increase was not significant against the control. The control treatment had the highest recorded rate of respiration response while the Ni:Zn (2.97 $\mu \mathrm{g}$ of c/g) and $\mathrm{Zn}(2.98 \mu \mathrm{g}$ of $\mathrm{c} /$ g) had the least. Among the other mesocosms, the Cu:Ni (3.06 $\mu \mathrm{g}$ of C/g) and Cu (3.04 $\mu$ g of C/g) had identical response values from measurement made by the $6^{\text {th }}$ week of the experiment. The microbial respiration response increased at about the same rate by the $2^{\text {nd }}$, 4 th and $6^{\text {th }}$ week across the mesocosms and the control. The authors assume that the plant root carbon may have masked the effect of the metal treatment, thereby providing sufficient opportunity for the soil microorganisms to deal with the organic input in soil. This culminated in the increase in metabolic activities of the microbial communities within the respective mesocosms. The increase in metabolic rates directly affected basal respiration measurements. Yang et al., (2007) observed similarly that plant production increases the metabolic activity of soil microbial communities, affecting their rate of specific respiration responses consequently.

\section{ACKNOWLEDGEMENTS}

The authors wish to acknowledge the staff of Chemistry Department of the University of Lagos, Nigeria fortheir[Akhnica Qlassistance. TThe authors equally express their gratitude to the authorities of the Federal Institute of Industrial Research Oshodi (FIIRO), Nigeria and the International Institute of Tropical Agriculture (IITA), Ibadan for providing opportunities that enabled successful execution of this study. DR. A. K Lawal of FIIRO is remembered for the provision of analytical grade reagents and offer of valuable assistance.

\section{REFERENCES}

Abdel-Ghani, N. T.; Elchaghaby, G. A., (2007). Influence of operating conditions on the removal of $\mathrm{Cu}, \mathrm{Zn}, \mathrm{Cd}$ and $\mathrm{Pb}$ ions from wastewater by adsorption. Int. J. Environ. Sci. Tech., 4 (4), 451-456 (6 pages).

Abdel-Ghani, N. T.; Hegazy, A. K.; El-Chaghaby, G. A., (2009). Typha domingensis leaf powder for decontamination of aluminium, iron, zinc and lead: Biosorption kinetics and equilibrium modeling. Int. J. Environ. Sci. Tech., 6 (2), 243-248 (6 pages).

Babel, S.; Opiso, E. M., (2007). Removal of Cr from synthetic wastewater by sorption into volcanic ash soil. Int. J. Environ. Sci. Tech., 4 (1), 99-107 (9 pages).

Bremner, J. M., (1965). Inorganic forms of nitrogen. In: Black, C. A., Evans, D. D. white, J. L., Ensminger, L. E., Clark, F. E. (Eds.). Methods of soil analysis. Part 2. Chemical and microbiological properties. Agronomy Monograph No. 9 ASA, Madison, America. 1179 - 1237.

Carney, K.; Matson, P. A., (2005). Plant communities, soil microorganisms and soil carbon cycling. Does altering the world below ground matter to ecosystem functioning? Ecosystems, 8 (8), 928-940 (13 pages).

Carney, K., Matson, P. A., Bohannan, B. J. M., (2004). Diversity and composition of tropical soil nitrifiers across a plant diversity gradient and among land - use types. Ecol. Lett., 7, 684-694 (11 pages).

Chander, K.; Brookes, P. C., (1991). Is the dehydrogenase assay invalid as a method to estimate microbial activity in copper - contaminated soils? Soil Biol. Biochem., 23 (10), 909 - 915 (7 pages).

Cherian, E.; Jayachandran, K., (2009). Microbial degradation of natural rubber latex by a novel species of Bacillus sp. SBS25 isolated from soil. Int. J. Environ. Res., 3 (4), 599604 (6 pages).

Dai, J.; Becquer, T.; Rouiller, J. H.; Reversat, G.; Berhard Reversat, F.; Lavelle, P., (2004). nfluence of heavy metals on $\mathrm{C}$ and $\mathrm{N}$ mineralisation and microbial biomass in $\mathrm{Zn}$-, Pb-, Cu-, and Cd-contaminated soils. Appl. Soil Ecol., 25 (2), 99 - 109 (10 pages). 
Giller, K.; Witter, E. E.; McGrath, S. P., (1998). Toxicity of heavy metals to microorganisms and microbial processes in agricultural soils: A review. Soil Biol. Biochem., 30 (10-11), 1389 - 1414 (26 pages).

Gueu, S.; Yao, B.; Adouby, K.; Ado, G. (2007). Kinetics and thermodynamics study of lead adsorption on to activated carbons from coconut and seed hull of the palm tree. Int. J. Environ. Sci. Tech. 4 (1), 11-17 (6 pages).

Hattori, H, (1992). Influence of heavy metals on soil microbical activities. Soil. Sci. Plant Nutr., 38 (1), 93 100 (8 pages).

He, Z. L.; Yang, X. E.; Baligar, V. C.; Calvert, D. V., (2003). Microbiological and biochemical indexing systems for assessing acid soil quality. Adv. Agron., 78, 89 - 138 (50 pages).

He, Z. L.; Yang, X. E.; Stoffella, P. J., (2005). Trace elements in agroecosystems and impacts on the environment. J. Trace Elem. Med. Biol., 199 (2-3), 125 - 140 (16 pages)

Hooper D. U.; Bignell, D. E.; Brown, V. K.; Brussaard, L.; Dangerfield, J. M.; Wall, D. H.; Wardle, D. A.; Coleman, D.C.; Giller K. E.; Lavelle, P.; Van der Putten, W. H.; De Ruiter, P. P. C.; Ruse, K. J.; Silver, W. L.; Tiedje, J. M.; Wolters, V., (2000). Interactions between aboveground and below ground biodiversity in terrestrial ecosystems: Patterns, mechanisms and feedbacks. Biosci. 50 (12), 1049 - 1061 (12 pages)

Igbinosa, E. O.; Okoh, A. I., (2009). Impact of discharge wastewater effluents on the physico-chemical qualities of a receiving watershed in a typical rural community. Int. J. Environ. Sci. Tech., 6 (2), 175-182 (8 pages)

Illmer, P.; Schinner, F., (1991). Effects of lime and nutrient salts on the microbiological activities of forest soils. Bio. Fertil. Soils., 11 (4), 261 - 266 (6 pages).

Kalembasa, S. J.; Jenkinson, D. S., (1973). A comparative study of titrimetric and gravimetric methods for the determination of organic carbon in soil. J. Sci. Food Agri., 24 (9), 1085 - 1090 (6 pages).

Kowalchuk, G. A.; Buma, D. S.; Boer, W. D.; Klinkhamer, P. G. L.; Van Veen, J. A., (2002). Effects of above ground plant specie composition and diversity on the diversity of soil - borne microorganisms. Ant. Van Leewenhoek, 81 (1-4), 509 - 520 (12 pages).

Leita, L.; De - Nobili, M.; Muhlbachova, G.; Mondini, C.; Marchiol, L.; Zerbi, G., (1995). Bioavailability and effects of heavy metals on soil microbial biomass survival during laboratory incubation. Biol. Fert. Soils, 19 (2-3), 103 118 (16 pages)

Li, Y.; Rouland, T. C.; Benedetti, M.; Li, F.; Pando, A.; Laveller, P.; Dai, J., (2009). Microbial biomass, enzyme and mineralization activity in relation to soil organic $\mathrm{C}$, $\mathrm{N}$ and $\mathrm{P}$ turnover influenced by acid metal stress. Soil Biol. Biochem., 41 (5), 969 - 977 (9 pages).

Malakootian, M.; Nouri, J.; Hossaini, H., (2009). Removal of heavy metals from paint industries wastewater using Leca as an available adsorbent. Int. J. Environ. Sci. Tech., 6 (2), 183-190 (8 pages).

Marschner, B.; Kalbitz, K., (2003). Control of bioavailability and biodegradation of dissolved matter in soils. Geoderma 113 (3-4), 211 - 235 (25 pages).
Marschner, P.; Yang, C. H.; Lieberei, R.; Crowley, D. E., (2001). Soil and plant specific effects on bacterial community composition in the rhizosphere. Soil Biol. Biochem., 33 (11), 1437 - 1445 (9 pages).

Moreno, J. L. F.; Bastida, M.; Ross, M.; Hernandez, T.; Garcia, C., (2009). Soil organic carbon buffers heavy metal contamination on semiarid soils: Effects of different threshold levels on soil microbial activity. Eur. J. Soil Biol., 45 (3), 220 - 228 (9 pages).

Nannipieri, P. E.; Kandeler, E.; Ruggiero, P., (2002). Enzyme activities and microbiological and biochemical processes in soil. In: Burns, R. G.; Dick, R. P. (Eds.). Enzymes in the Environment. Marcel Dekker, New York.1 - 34.

Niklinska, M.; Laskowski, R.; Maryanski, M., (1998). Effects of heavy metal and storage time on two types of forest litter: basal respiration rate and exchangeable metals. Ecotox. Environ. Saf., 41 (1), 8 - 18 (11 pages).

Nwuche, C. O.; Ugoji, E. O., (2008). Effects of heavy metal pollution on the soil microbial activity. Int. J. Environ. Sci. Tech., 5: 409 - 414 (6 pages).

Okafor, E. Ch.; Opuene, K., (2007). Preliminary assessment of trace metals and polycyclic aromatic hydrocarbons in the sediments. Int. J. Environ. Sci. Tech., 4 (2), 233-240 (8 pages).

Oshode, O. A.; Bakare, A. A.; Adeogun, A. O.; Efuntoye M. O.; Sowunmi, A. A., (2008). Ecotoxicological assessment using Clarias gariepinus and microbial characterization of leachate from municipal solid waste landfill. Int. J. Environ. Res., 2 (4), 391-400 (10 pages).

Panjeshahi, M. H.; Ataei, A., (2008). Application of an environmentally optimum cooling water system design in water and energy conservation. Int. J. Environ. Sci. Tech., 5 (2), 251-262 (12 pages).

Perez - de - Mora, A.; Madrid, F.; Cabrera, F.; Madejon, E., (2007). Amendments and plant cover influence on trace element pools in a contaminated soil. Geoderma 139 (12), 1 - 10 (10 pages).

Petersen, S. O.; Klug, M. J., (1994). Effects of sieving, storage and incubation temperature on the phospholipid fatty-acid profile of soil microbial community. Appld. Env. Microbiol., 60: 2421 - 2430 (10 pages).

Rorga, P.; Nilsson, M.; Tunlid, A., (1994). Bacterial communities in peat in relation to botanical composition as revealed by phospholipid fatty acid analysis. Soil Biol. Biochem., 26: 841 - 848 (8 pages).

Schloter, M.; Dilly, O.; Munch, J. C., (2003). Indicators for evaluating soil quality. Agric. Ecosyst. Environ., 98 (13), 255 - 262 (8 pages).

Smith, J. L.; Paul, E. A., (1990). The significance of soil microbial biomass estimations. In: J. Bollag; G. Stotsky (Eds.) Soil biochemistry. Marcel Dekker, New York, New York, USA.

Stephan, A.; Meyer, A.; Schmid, B., (2000). Plant diversity affects cultivable soil bacteria in experimental grassland communities. J. Ecol., 88 (6), 988 - 998 (11 pages).

Suthar, S.; Singh, S., (2008). Vermicomposting of domestic waste by using two epigeic earthworms (Perionyx excavatus and Perionyx sansibaricus). Int. J. Environ. Sci. Tech., 5 (1), 99-106 (8 pages).

Torkian, A.; Keshavarzi Shirazi, H.; Mehrdadi, N., (2007). Fate of intermediate biodegradation products of triethyl 
Effect of co-existing plant specie on soil microbial activity

amine in a compost-based biofiltration system. Int. J. Environ. Res., 1 (2), 163-169.

Vance, E. D.; Brookes, P. C.; Jenkinson, D. S., (1987). An extraction method for measuring soil microbial biomass C. Soil Biol. Biochem., 19 (16), 703 - 707 (5 pages).

Vig, K.; Megharaj, M.; Sethunathan, N.; Naidu, R., (2003). Bioavailability and toxicity of cadmium to microorganisms and their activities in soil: A review. Adv. Environ. Res., 8 (1), 121 - 135 (15 pages).

Yang, R. J.; Tang, J.; Chen, X.; Hu, S., (2007). Effects of co existing plant species on soil microbes and soil enzymes in metal lead contaminated soils. Appl. Soil Eco., 37 (3), 240-246 (7 pages).

Zak, D. R.; Holmes, W. E.; White, D. C.; Peacock, A. D.; Tilman, D., (2003). Plant diversity: Soil microbial communities and ecosystem function, Are there any links? Ecology 84 (4), 2042-2050 (9 pages).

Zvinowanda, C. M.; Okonkwo, J. O.; Shabalala, P. N.; Agyei, N.M., (2009). A novel adsorbent for heavy metal remediation in aqueous environments. Int. J. Environ. Sci. Tech. 6 (3), 425-434 (10 pages).

\section{AUTHOR (S) BIOSKETCHES}

Nwuche, C. O., M.Sc., Department of Microbiology, University of Nigeria, Nsukka, Nigeria. Email: charlesnwuche@yahoo.com

Ugoji, E. O., Ph.D., Department of Botany and Microbiology, University of Lagos, Akoka, Lagos, Nigeria. Email: ugojie@gmail.com

How to cite this article: (Harvard style)

Nwuche, C. O.; Ugoji, E. O., (2010). Effect of co-existing plant specie on soil microbial activity under heavy metal stress. Int. J. Environ. Sci. Tech., 7 (4), 697-704. 